\title{
A Critique of the Creative Economy, Creative City and Creative Class From the Global South
}

\author{
Diego Santos Vieira de Jesus ${ }^{1}$, Daniel Kamlot ${ }^{1}$ \& Veranise Jacubowski Correia Dubeux ${ }^{1}$ \\ ${ }^{1}$ Creative Economy Management, ESPM-Rio, Brazil \\ Correspondence: Diego Santos Vieira de Jesus, Executive Master Program in Creative Economy Management, \\ 90-Centro, Rio de Janeiro-RJ, ESPM-Rio, Brazil. Tel: 55-212-216-2002.
}

Received: May 8, 2020

doi:10.5430/ijba.v11n4p1
Accepted: May 22, 2020

Online Published: June 7, 2020

URL: https://doi.org/10.5430/ijba.v11n4p1

\begin{abstract}
The aims are to identify and examine the inconsistencies and incongruities of the definitions of "creative economy", "creative city" and "creative class" in their application to the study and the formulation of public policies in the Global South. The central argument points out that 1) the idea of "creative economy" seemed to conceive peripheral societies would be flat tables on which pre-given economic governance strategies for creative sectors could be replicated; 2) the concept of a "creative city" by the mainstream does not deal with the specific political-economic obstacles in the Global South, so it seems more feasible to define "creative city" from a culturally specific understanding of what creativity is and recognize the motivations for creating a creative city can come from different actors according to local circumstances; 3 ) the mobilization of creativity in the exercise of the profession is a weak criterion for defining the "creative class", which motivates difficulties regarding the self-identification of individuals as members of it. They reproduce hierarchical regimes that exclude differences.
\end{abstract}

Keywords: creative economy, creative city, creative class, critical perspective, Global South

\section{Introduction}

In the early 1980s, the expression "creative city" referred to an effort by the artistic community to justify the economic value of its production in the territory of cities, especially in the United States, United Kingdom and Australia, and later throughout Europe. At the end of that decade and in the early 1990s, conferences discussed how arts and culture could be better integrated into the planning process for the development of the city, and reports produced by Landry (2011) brought the first strategies for urban creativity, focusing on the city as a "creative organism". When Australian Prime Minister Paul Keating launched the Creative Nation Project in 1994, it was an important step in emphasizing the state's openness to the world, since culture was recognized as an identity and economic resource. Landry (2011) highlighted, in the mid-1990s, the need to expand the concept of "creative city" beyond its focus on artistic activities and emphasized the need to incorporate themes such as organizational dynamics to foster creativity. In the 2000s, the author contrasted the "urban engineering paradigm", focused on hardware, and "creative process", based on the ways in which understanding the city's software would help to reconstruct it (Landry, 2011).

The development of territories called "creative cities" has made it possible to place certain cities as centers of attraction for creative talents, since culture adds value and operates as a source of inspiration, generating an environment more inclined to valuing creativity. Creative sectors that make up the context of the so-called "creative economy" - such as advertising, architecture, arts and antiques market, crafts, design, fashion design, cinema, software, interactive software for leisure, music, performing arts, publishing industry, radio, TV, museums, galleries and activities related to cultural traditions (Bendassolli et al., 2009) - may, according to some of the main proponents of this expression (Hartley, 2005; Howkins, 2001) improve the quality of life and help to increase attractiveness economic environment to a class of people who make up the so-called "creative class", composed of sociocultural and economic agents whose ideas and production would be fundamental for the promotion of the socioeconomic development of the cities in which they live or work (Reis, 2011).

Since the discussions at the United Nations Conference on Trade and Development (UNCTAD) in the early 2000s, the concept of "creative city" has been put by state leaders as central to promoting the development of the planet's periphery, because such promotion requires more localized and specific actions, which can be carried out in cities, 
but not necessarily in entire states (Vlassis \& Beukelaer, 2019). However, this concept - as well as the ideas of "creative economy" and "creative class" - was conceived in a reality different from the peripheral states, in academic and political debates in which representatives of such countries had limited or no participation. The result is the existence of innumerable inconsistencies between the concepts defined from experiences of cities in the Global North and the reality of the so-called "creative cities" in peripheral states, so that the treatment of context, territory and people brought about in these concepts do not necessarily correspond to the situation experienced in countries in Latin America, Asia or Africa.

With this in mind, the aims of this article are to identify and examine the inconsistencies and incongruities of the definitions of "creative economy", "creative city" and "creative class" in their application to the study and formulation of policies public in the Global South states. The central arguments point out that:

1) The idea of "creative economy", in addition to widening the gap between the wealth of innovators, investors and shareholders who own the capital and those on whose work they depend, seemed to conceive that peripheral societies would be flat tables in which predefined formulas of socioeconomic governance that operated in North Atlantic societies for the development of creative sectors could be replicated, not taking into account local particularities;

2) The concept of "creative city" developed by the mainstream does not deal with the specificities of the political and economic obstacles of the Global South, so that it seems more feasible to define "creative city" based on a culturally specific understanding of what creativity is and recognize the motivations for creating a creative city can come from different actors, according to the specific political and socioeconomic circumstances of each location;

3) The mere mobilization of creativity in the exercise of the profession is a fragile criterion for the definition of a "creative class", given not only the diversity of sectors that have their own needs and demands, but which are also marked by differences in terms of salaries, working conditions and exercise of creativity among the professionals themselves who work within the same creative sector or among different sectors. In addition to the difficulties related to the self-identification of individuals as members of this class, professionals in the sectors that compose it reproduce hierarchical regimes that segregate, exclude and marginalize differences, particularly in developing countries, in which these regimes are more rooted in face of historical gaps in terms of guaranteeing rights to such differences.

\section{Method}

A qualitative method was adopted to deepen the existing knowledge about creative economy, creative city and creative class. All information collected by bibliographical research was analyzed in light of the most recent understandings of the subject and in view of the Global South context. Having obtained the relevant data concerning the topics of interest, we analyzed it, discerning what was related to each category ("creative economy", "creative city" and "creative class") and exploring the main omissions and contradictions of mainstream authors when dealing with the development of creative economy, cities and class in Latin American, Asian and African countries.

\section{Results}

\subsection{The Creative Economy}

The productive activities that are part of the creative economy are linked to new ways of production and consumption at a time of restructuring of capitalism, which, according to much of the literature about this economy (Hartley, 2005; Howkins, 2001; Miguez, 2007; Reis, 2006, 2008; Venturelli, 2000), is characterized by the logic of innovation in an invention regime instead of a hegemonic one, based on reproduction and the development of the industrial economy. The creative economy activities refer to the production, distribution and consumption of goods and services based on texts, symbols and images and the diverse set of activities based on creativity, talent or individual skill, which bring products that incorporate intellectual property (Miguez, 2007). In addition to the numerous differences in the academic debate and also in the discussions about which sectors would comprise such an economy - which, in the political dimension, has often to do with political-economic interests of appreciation of specific sectors by the governments -, this definition often seems to conceive that the creative economy would be limited to the processes and activities of the creative sectors, which often generates conceptual confusion when authors from peripheral countries point out that the expression can refer not only to creative sectors, but to the application of creativity to a series of solutions for social problems related to health, public security, education and urban mobility, for example. In this sense, creativity would not be confined to the creative sectors, and the creative economy could even include the application of creative processes or actions to deal with social issues that transcend such sectors, including traditional sectors of economies, such as agriculture and classical industrial activity (Figueiredo et al., 2019a; Jesus \& Dubeux, 2018). 
According to much of the literature, the motivations for the transformations in the capitalist system that led to the creative economy occurred in the light of the transition from materialistic to post-materialistic values, in the context of which it seeks to meet the aesthetic and intellectual needs of individuals and develop the knowledge society, based not on the intensive use of capital and labor, but on people's intellectual resources, the formation of social networks and the exchange of knowledge (Bendassolli et al., 2009; Florida, 2002; Howkins, 2001). Originality and innovation are seen by some of the mainstream experts as defining elements of the creative economy, and information and communication technologies are understood as capable of transforming management processes and market culture through the generation of networks and collaborative models. This generation affects production through new vehicles for creative content, brings the possibility of new products and services based on digital media and creates opportunities for the mobilization of increasingly versatile teams, which coordinate skills, specialties and resources via such technologies. The distribution of creative products also changes through the inclusion of alternative channels, which would increase global access and minimize transaction costs. Finally, consumption also changes, enabling consumers to seek creative goods and services - typically considered to be of infinite variety and perennial for being enjoyed for long periods - and even access them directly from the producer (Reis, 2008). In such a context, the construction of subjectivities and personal identities by the consumers occurs when they also become agents in the generation of economic value in leisure, entertainment and the new regimes of symbolic distinction (Bendassolli et al., 2009). Many elements described by these authors have been reinforced recently by Towse \& Hernández (2020).

Bendassolli et al. (2009) recognize that, due to the instability of demand, producers and creative managers have limited capacity to predict commercial success, and products cannot always benefit from previous experiences, which become an even more serious problem in societies with a lower level of economic development. Companies often end up seeking innovations with no guaranteed financial return. Kerrigan et al. (2020) argue that, in a predominantly neoliberal world, success is valorised, particularly for individuals, while failure is often hidden or perceived as negative, but the relationship between success and failure is deeply symbiotic and should be examined from a systemic rather than an individual view. According to the authors, creative practice emerges out of a system where an individual is placed in a relationship to social and cultural factors that enable and constrain creative opportunities.

Reis (2008) recognizes, as Figueiredo et al. (2019b) also do so when analyzing the potential for the development of the creative economy in Brazilian capitals, which the concentration of creative sectors in certain regions can aggravate contrasts within the territory of the peripheral states. In addition, the author also points out that peripheral states may have more difficulties in financing creative ventures, given that goods and services are intangible assets difficult for investors to value, so that these ventures are often associated with high risk. The existing regulatory frameworks in societies in the Global South are often inadequate to manage the conflict between the creator's individual financial remuneration rights and the rights of public access to the generated knowledge. The appropriation of technologies faces cost and regulatory difficulties, in addition to gaps related to the necessary knowledge and skills for the creative activities and sectors in the light of the prioritization of technical issues in educational systems, with no effective stimulus to reasoning capacity and the expansion of the individual and collective talent of the students (Reis, 2008). Although Bendassoli et al. (2009), Reis (2008) and Figueredon et al. (2019b) have the merit of recognizing that there are problems in the conditions and the development of the creative economy in peripheral states, little is considered about the motivations of these problems, which ends up making them aware of the incompatibilities between the concepts developed by North Atlantic authors and the creative economy that develops in Latin-American, Asian and African countries, but they reproduce the concepts uncritically, trying to make the reality of the creative economy in peripheral countries fall into concepts that were thought, debated and applied to places with distinct levels of human and social development.

\subsection{The Creative City}

Assuming the relevance of knowledge and creativity as territorial resources that can reinforce competences through differentiation and generate employment and income (Figueiredo, 2015), territorial development policies in numerous places around the world recognized the need to develop "creative territories", which, according to Trip (2009), combined the preservation of cultural and environmental values towards the integral and sustainable development in a context of globalization, the strengthening of science and technology and the consumption of symbolic values. According to Messias et al. (2020), the relationship between the creative and sustainable paradigms is a consequence, rather than a first intention, of a proclaimed paradigm aimed at breaking away from the twentieth century models of development. 
The stimulus to "creative cities" would provide incentives for territorial development, local empowerment, mental openness, imagination and public participation (Trip, 2009). The concept of "creative city" is often used in reference to cities in which the articulation among social and artistic activities, creative sectors and government has attracted talent, promoted social diversity and strengthened the creative potential of companies and institutions. For Landry (2011) - one of the main authors to explore this concept -, a creative city aggregates urban identity, heritage, physical and technological models of communication among inhabitants, mechanisms for minimizing conflicts and full acceptance of diversity.

Landry and Bianchini (1998) suggest a "toolkit" for generating a creative city, which already points out how standardizing a North-Atlantic work is. It is placed as a privileged speech to determine a model for structuring creative cities anywhere in the world, as if other societies were flat tables and receptacles of preconceived formulas for urban and regional development. Such recommendations and guidelines - which revolve around the points presented above by Landry (2011) - seem to point to an ideal type of "creative city" that even in cities in central states is not possible to be found, although some cities in these states are closer to this type than those in the Global South. The situation is aggravated when such a model is confronted with the socio-political and cultural realities of different cities in the developing world, in which several urban problems are accentuated, such as urban violence - in the light, for example, of threats such as drug trafficking and the presence of militias and paramilitary groups - and issues with urban mobility, especially the difficulties in transporting production to the main markets and the mobility of people, an argument that is even indicated by Scott (2019), but not fully developed. Although problems like these can also occur in creative cities in Global Northern countries, the management of these issues typically takes place more effectively than in peripheral states due to the greater amount of resources available to solve these problems and more effective mechanisms for the accountability of public authorities (Mainwaring, 2003).

Regarding the structuring of creative ventures, those that develop in different creative cities around the world are still characterized by informality, generating creative activities that often compete for space with formal creative businesses and rarely come with robust mechanisms of intellectual property protection for creative professionals. These professionals are still subject to fragile labour relations and exploited even more than they were in the industrial economy. The excess of informality also generates difficulties in the production of data on creative sectors in these cities, which causes obstacles not only for academic analysis (Figueiredo et al., 2019b), but also for the formulation of public policies, which would require such data for their improvement, as well as the expansion of their effectiveness.

The "creative city" must, according to Chantelot et al. (2011), be provided with a gross infrastructure of cultural equipment, an efficient transportation system and basic sanitation, and a soft infrastructure that includes a skilled and flexible workforce. The prerequisites for the establishment of a creative city are the directing of resources for strategic works and the coordination of efforts among different levels of government to raise funds, stimulate public participation, integrate the population into the labour market and encourage the creation and strengthening of local businesses. According to Reis (2011), the motivating elements of such modifications may be the city deindustrialization, the search for greater tourist mobility, the incentive to redefine spaces or even the appreciation of culture as an economic sector and a condition for the formation of creative environments in contexts of international sports competitions or major cultural events.

\subsection{The Creative Class}

In the context of the transformations of capitalism, much of the literature on creative economy seemed to take the endowment of individuals in terms of creative and artistic capacities for granted. Allied with managers and professionals in the technological area, they could design products and services whose economic value would be in their cultural or intellectual properties (Howkins, 2001; Miguez, 2007; Reis, 2006, 2008). The treatment of themes related to "creative professionals" became more notable in Florida's work $(2002,2005)$ with the concept of "creative class", composed, according to the author, of knowledge workers who lead the generation of wealth in cities and regions through intellect and creativity. Such a group includes lawyers, engineers, software developers, musicians and artists who operate in sectors such as fashion, cinema and TV. Using an extensive interpretation of the mobilization of creativity in the occupations of professionals, the author argues that occupations whose main aspect is the use of creativity in their productive activities generate socioeconomic and cultural dynamism (Florida, 2002). More recently, Florida \& Mellander (2020) argued that, although the role of human capital in shaping cross-national innovative and economic performance is well-understood, it is an indirect measure of skill, based on educational attainment. The authors introduce and test a more direct measure of skill, based on work that is actually performed, 
measured by occupation. Such occupational "classes" play an important role in regional economic performance, outperforming human capital in some cases.

Although the term "class" can be defined in multiple ways, it typically refers to a group of people who have a similar social status based on multiple criteria, such as income. The mere mobilization of creativity in the exercise of the profession - which virtually makes the possibility of individuals who are considered members of the "creative class" border on infinite - is a fragile criterion for the definition of a class in light of not only the diversity of sectors which have their own needs and demands, but which are also marked by differences in terms of wages, working conditions and the exercise of creativity among the professionals themselves, who work within the same creative sector or between different industries. Another issue that arises in relation to the breadth of the concept of "creative class" is the difficulty of self-perception of creative professionals as members of the same class, given that many of these professionals are unable to identify what is effectively in common with other members, in addition to the fact that, for the most part, they have their own interests regarding their sector or category. Many members of creative sectors have demands and claims that clash with other members of the same sector or different industries, in a way that breaks up ideas of unity and cohesion that a class presupposes.

By understanding that the "creative class" concept indicates the consideration of people as decisive resources in the economy, Florida (2002) argues that socioeconomic growth is based on three "Ts": "talent" - which drives this growth -, "technology" and "tolerance", fundamental in attracting human capital. Florida $(2002,2005)$ indicates that occupations in the "creative class" can promote social inclusion and reduce disparities based on gender, sexual orientation, income, origin and race, for example. The author conceives that culture would create a society in which talent could be developed by allowing an open and inclusive environment, which would enable people to validate their multiple identities and use technology to search for innovations from their varied contributions (Florida, 2002, 2005). However, systemic constraints, mainly in peripheral societies, are marginalized in the author's reflections. It becomes difficult to think about the development of talent or individual and collective skills and aptitudes with serious educational deficits and the inadequacy of educational programs to the demands of a critical and creative society. As Araya (2010) points out, transdisciplinarity between three pillars of knowledge - technical-scientific, cultural-creative and entrepreneurial pillars - is fundamental to the development of talent, considering that the first two allow introducing new topics of knowledge to the creative sectors and the latter turns them into products and services valued by the market and society. A "creative education" would develop these pillars in students, in addition to appreciating traditional knowledge and the formation of critical thinking in the light of political-economic and socio-cultural dynamics. However, it is difficult to imagine the development of such education in the light of problems faced by peripheral countries, such as the diversion of funds from education to private groups and politicians and the maintenance of the position of many of these countries as commodities exporters, which does not encourage the training of professionals who do not work in the production of these goods.

\section{Discussion}

\subsection{The Revised Creative Economy}

There is the possibility to use more critical references about the development of the creative economy in global and local scopes, which allow investigating that the controversial issues related to the creative economy transcend those cited by the authors presented above. In the global dimension, it is recognized that such an economy may have modified global arrangements in the context of the Fourth Industrial Revolution, in which physical and virtual production systems cooperate and interact in a global and flexible way, allowing the customization of products and the generation of organizational models. However, the creative economy has not necessarily led to a rethinking of political and social systems, so that institutional frameworks continue, in many regions of the planet, to reproduce and even exacerbate the socioeconomic inequalities that existed since the beginning of the development of capitalism, but under a new guise. The great beneficiaries of such a revolution in which the creative economy appears in the leadership seem to be the providers of intellectual or physical capital, as innovators, investors and shareholders, in such a way that the gap between the wealth of those who own the capital and those who work for them is widened. Organizations that pair buyers and sellers of goods and services enjoy increasing returns to scale, which means that few powerful platforms will dominate creative markets. Although there are benefits to consumers, such as lower prices and more convenience, the social costs are evident, given that the existing forms of governance have not been able to globally balance the benefits and risks of the forms of creative endeavours generated by the Fourth Industrial Revolution (Schwab, 2016).

In the local spheres, some of the leading specialists who dedicated themselves to the study of creative economy (Landry, 2011; Landry \& Bianchini, 1998) seemed to ignore that the transformations in the capitalist system often 
did not occur in a homogeneous way in time and space, in a that, in the face of the ongoing changes, traces of industrial or even traditional societies can coexist in a hybrid and, often, complementary and non-disruptive way with the creative economy. Some authors seemed to conceive that societies would be blank tables in which pre-defined formulas of socioeconomic governance that operated in North Atlantic societies for the development of the creative economy could be replicated not considering local particularities. In the face of such attempts at homogenization that seek to generalize hegemonic perspectives about a phenomenon for the understanding of others, it is possible to say that, in the practice of the development of the creative economy, the potential universalism of pre-conceived formulas to stimulate such an economy will be crossed by particularisms of national or local dimensions, which can create barriers to such an economy (Mann, 2012). Regarding peripheral states, Santos (1996) defends the need to build a theoretical body that understands, analyses and reports regional problems in the global periphery and emphasizes social inequalities and contrasts with the developed world. In line with the argument put by the author in relation to geography, the development of knowledge about the creative economy de-historicized and dehumanized social processes. Even when placing itself as an area of interdisciplinary and / or transdisciplinary knowledge, studies on creative economy started with an "abstract empiricism", which seemed to replace real social relations with ideal relations between objects of study.

Santos (1996) recognizes that the capitalist mode of production imposes an accumulation rhythm that implies a differential endowment of work instruments, which results in a distribution in the "unequal and combined" space of income. Since the creative economy would be a reinvention of this order that does not radically alter its exclusionary political-social bases, the proposal stimulated by several scholars that such an economy can promote effective social inclusion (Howkins, 2001; Miguez, 2007; Reis, 2008) sounds illusory. The idea of the promotion of social inclusion by creative economy has been highlighted in the debate about the formulation and implementation of public policies in several countries, including peripheral ones, and international institutions such as the United Nations Educational, Scientific and Cultural Organization (UNESCO) and UNCTAD. Some pre-given and homogenizing formulas, present in initial reports produced by these institutions about the implementation of the creative economy in several countries and strengthened by many North Atlantic academics, came up against totally different political, economic and cultural realities, so that the development of the creative sectors that happened in certain countries would be unfeasible in others, given the incompatibility of the particularities and specificities of these societies in relation to the recommendations that came from international bodies (Vlassis \& Beukelaer, 2019). The stimulus to innovation and originality of the fundamental ideas for the development of creative sectors, for example, should be enhanced, according to Venturelli (2000), by public policies at different social levels, leading to the structuring of an educational system that emphasizes creative freedom and independent thinking, as well as state and private investments in research and development of new ideas and technologies and the search for risk reduction for creative enterprises.

However, when recommendations like these are applied to peripheral states and local particularities are considered, one can observe their inadequacy or unfeasibility in view of the socio-political and economic realities of such countries. In the political dimension, some issues need to be taken into consideration, such as the discontinuity of public policies - often arising from changes in government and financial restrictions -, the deficiency of technical staff and the worsening of corruption, structured in the apparatus of numerous peripheral states through the creation of personal ties and expressed in relationships and practices that benefit specific groups and elites to the detriment of most of the population (Bezerra, 2012). In addition, the maintenance of clientelist relationships results in a greater dependence of creative professionals in relation to the favours of government managers (Jesus \& Kamlot, 2017). In this context, references to the potential for generating income and jobs - hence the greater need for alternative financing resources for creative ventures and professional training for workers in the creative sectors - and urban regeneration brought about in the political discourse related to the creative economy can, in the case of peripheral countries, be related to electoral purposes or the creation of forged feelings of cohesion and national or local identity aiming at the political manipulation of populations (Jesus \& Kamlot, 2018).

In such countries, political crises - which may involve the diversion of funds for the development of the creative economy in areas such as creative education, research and innovation - can lead to economic recession, excessive dependence on commodities for the economic health of the place and a drop in tax revenue by the governments (Jesus, 2019). In some other countries, elements such as ethnic cleavages, religious extremism and civil wars can compromise governance apparatus that allow the development of the full potential of creative activities in promoting peace, stabilizing societies and bringing economic growth, obstacles that much of the literature on creative economy disregarded when preaching the replication of "formulas of social transformation" both in the academic dimension and in political discourse. 
The economically low-income population, when abandoned by the state in the social and economic dimensions, can seek, through violence, to satisfy basic needs and consumption desires. Urban violence makes it difficult to create areas of engagement among creative professionals and the formation of creative hubs. The combination of political and economic elements that compromise the functioning of the state - and that can be stimulated by internal elements, such as restrictive economic policies and contingencies, and external elements, such as global economic-financial crises or trade wars between states - undermines the conditions of possibility so that creative sectors can operate as promoters of human and social development and increase the risks associated with investing in creative sectors. In addition, the profound informality to which most of the creative sectors in the periphery are subjected is linked to labour rules that leave the creative professional even more vulnerable and exposed to political and economic instability, as well as the permanence of regulatory frameworks that do not guarantee the intellectual property rights of the professionals, not only because of the need to disseminate knowledge and culture - which is typically reinforced in political discourse -, but because of the technical deficiency of bodies that should be responsible for protecting such rights and the lack of preparation of specialized professionals to perform such tasks.

Still with regard to the interactions between the local and global dimensions, Reis (2008) points out that the creative economy could be a development strategy for peripheral states, since it recognizes the relevance of human capital to promote the integration of socio-cultural objectives and thus opens up a range of opportunities based on creative endeavours, allows the formalization of small businesses, promotes the generation of income and employment and increases the well-being of the population by stimulating the expression and participation of citizens in political life. This would be possible, according to the author, because of the intangibility of creativity, which creates additional value by incorporating cultural characteristics, inimitable par excellence, and creating synergies between the lifestyle and the environment in which it flourishes (Reis, 2008). However, it is essential to emphasize that not all states that have adopted development strategies based on the creative economy have achieved the expected results. Many abandoned the strategy or saw the increase of regional and local disparities when implementing them - as shown by Figueiredo et al. (2019b) when mentioning the Brazilian case - and that the appreciation of local cultures took place in an intermittent, discontinuous, unequal and not rarely opportunistic manner among the various creative sectors. Not only did mass culture continue to invade markets in peripheral countries, but elements of specific cultures were pragmatically incorporated into larger productions to even create specific niche markets, which, instead of valuing the richness of local and regional cultures, take ownership of them, empty the critical content that many carry in terms of preserving memory and create the illusion that a greater representativeness of these cultures would necessarily incorporate greater respect for their wealth of themes and issues, as seen in creative sectors such as the audiovisual and music industries, for example. The greater representativeness was not enough for stereotypes and prejudices regarding differences to be eliminated.

\subsection{The Revised Creative City}

It is necessary to make critical considerations regarding the elements mentioned by Chantelot et al. (2011) and Reis (2011) - which are also reinforced by Landry (2011), Landry and Bianchini (1998) and Trip (2009) -, particularly with regard to the idea that such cities should bring incentives for greater mental openness - with a view to promoting innovation - and a full recognition of diversity. If such definitions were fully applied, it would be inconceivable, for example, to imagine the existence of creative cities in authoritarian or semi-authoritarian countries, in which individual freedoms were restricted by the government and police apparatus, as in the People's Republic of China, for example. However, Beijing and Shanghai are often cited as "creative cities" even by North Atlantic literature (Landry, 2011; Florida, 2002), which would already expose a contradiction in the argument of these authors. Similar situations apply to states in Eastern Europe, Southeast Asia and much of the African continent. Considering Latin America, it can be seen that, although most states can be considered "democratic", most forms of expression of freedom of expression and instruments of political engagement are emptied, and the mechanisms of popular participation are unknown in the face of serious educational deficits or are strongly repressed by authorities, particularly in times of crisis. In addition, access to creative goods and services remains restricted to elites in many of these cities - especially those linked to information and communication technology -, as well as to jobs linked to these activities, the educational services that would allow the insertion of citizens in creative sectors or even the recognition of the relevance of material and immaterial heritage in the preservation of memory and critical reflection for the development of solutions to urban issues in the present (Jesus, 2017).

The presence of "creativity" - a concept that, in the dominant literature in creative economy studies, seems to refer to the expression of the human potential for realization in activities that generate tangible products and the ability to manipulate symbols and meanings in the search for innovations (Bendassolli et al., 2009) - in certain cities did not necessarily presuppose the existence of democracy or its full experience by the population to foster the multiplicity 
of ideas for creative production or even the solution of urban issues. Mechanisms of segregation and socio-political and economic exclusion of countless citizens continue to exist in several cities classified as "creative" - even in developed states - so that the experience of a full democracy as a prerequisite for the establishment of a "creative city" as defined by North Atlantic literature does not seem feasible even in the places where the concept originated.

In addition, the motivating elements of a creative city do not necessarily fit those indicated by Reis (2011), nor do they even assume there is coordination of efforts among different levels of government and citizens. Regarding the motivating elements, it can be mentioned that the stimulus to creative industries can also be linked to elements such as nationalism and separatism - especially those linked to community traditions, which reinforce social cohesion and can even serve as a focus of resistance or struggle for independence - and the maintenance of repressive elements by states that create, through artistic, cultural and creative productions, official narratives that aim to generate the population's sense of belonging to the place and divert people's attention from political mobilization for better living conditions. When the particularities of local conditions are considered, the specificties of the motivating elements of a creative city may be more precislely explored. Karvelyte (2020), for example, argues that, while the appeal of the creative city is typically attributed to urban entrepreneurialism, this is insufficient in explaining the so-called "cultural turn" in Shanghai, Hong Kong and Taipei, because none of them ascribe to the conventional format of the post-industrial entrepreneurial city. One of the major forces driving the adoption of creative city initiatives in these places is the inherited cultural policy agenda, which largely stems from national interests and plays a significant role in directing and changing the "global cultural city" making process.

Governmental and population engagement for a creative city, placed as a prerequisite for its development by so many authors, as cited by Landry (2011), assumes that a creative city must be conceived from spontaneous mobilization or stimulated by initiatives and proposals for its emergence. However, in cases such as the People's Republic of China, Russia and other authoritarian and semi-authoritarian states, the initiatives start from government plans with no expressive consultation or popular participation at the time of their formulation, and mobilization around creative sectors is imposed or forced, starting from government initiatives. Kolobova (2020), for example, argues that the state investment program of renovation of Moscow solved several complex problems: the unloading of transport infrastructure; the creation of a new urban barrier-free environment adapted for comfortable living, recreation and work; the construction of energy-efficient apartment buildings; the improvement of the environmental situation of residential buildings; the repair and modernization of engineering infrastructure; and the formation of modern architectural appearance. The program can be considered as an integral part of the overall program for the creation of a creative city, or as a sub-program for the creation of Russia's creative capital.

The incentive for the creation and development of creative cities can be either "top down" as a government decision / policy, or "bottom up", based on spontaneous population movements and, as Vivant (2012) and Scott (2019) point out, from socioeconomic actors in search of the benefits of "agglomeration economies". Alexandri \& Raharja (2020) see the relevant role of small and medium enterprises when they map the performance and competitive advantage of these companies in the creative industries in Bandung City, declared as a creative city by UNESCO in 2015. The development of Bandung as a creative city has been formulated in its creative city road map which sets six indicators: creative policy; creative infrastructure; law, ethics and intellectual property rights; creative support system; creative capacity and economic contributions.

It seems more feasible and coherent, therefore, to define a "creative city" based on a culturally specific understanding of what creativity is, since it does not necessarily presuppose that there is the same level of collaboration and engagement as the dominant literature on creative cities seems to conceive, and the motivations for the creation of a creative city can come from different actors, according to the specific political and socioeconomic circumstances of each location.

The concept of "creative city" has already been the target of several criticisms by countless experts around the world. Closs et al. (2014) argue that the urbanism model in which the concept fits proved to be linked to economic imperatives and a neoliberal agenda, which relegates potentially negative redistributive effects in the background. In addition, the encouragement of pasteurized forms of creative activities can occur at the expense of investments in social welfare, education, health or support for forms of creativity other than those valued by local elites. The "competitive cosmopolitanism" that makes creative cities develop their own brands redraws models of entrepreneurship and urban governance that attract volatile capital and generate an illusion that habitability is for everyone (Closs et al., 2014). The development of creative cities does not necessarily transform the context in which wealth disparities develop, and the risks of gentrification and social exclusion are still evident. The application of urban development formulas with no consideration for the specific local circumstances can lead to the failure to 
effectively build a creative city (Miles, 2014), as defined by the dominant literature on the topic. Although the relevance of the criticisms presented by these authors is recognized, one can see that there are additional controversial issues in the very origin of the concept and the attempts to define the elements that compose and build a "creative city".

\subsection{The Revised Creative Class}

Bendassolli \& Wood Jr. (2010) recognize that technology can be used by institutions to expand their control over employees, so that the supposed "flexibility" that professionals in the "creative class" have can be associated with the exploration and the extension of external control of their domestic and professional lives. However, when dealing with the challenges of societies in the periphery of the planet, the problems related to technology transcend the ones pointed out by the authors. Such issues are related not only to the development of new forms of exploitation of workers, but also to the limitation of opportunities for the development of technologies that could alleviate the alarming socio-economic situation in which many of these societies are immersed and also the creative professionals who are dedicated to innovation. According to Rendra \& Rahmat (2020), the insistence of challenges from digitalization and transformation of the 4.0 era made the government and the people of Bandung improve 21st century creative competencies in a process that involved the city government, the creative community and the residents. The coaching process had a top-down and bottom-up direction and was carried out through policy and non-policy competency development programs from the government and community collaborative forums. The process also included the analysis of program plans and the evaluation of results.

Despite some successful initiatives, it is difficult to conceive the stimulus to technology in societies in which not only corruption is present, but also government policies limit the development of academic research, taking into account, for example, the recent restrictions of funds made by the Brazilian government to research, mainly affecting federal universities. Initiatives like this can dismantle research groups and lead to brain drain to other countries where researchers find better working conditions. The realization of the government's role as an instigator and financier of companies based on new technologies and research ends up being hampered, as well as its cooperation with the private sector and universities. Companies typically invest more in innovation during crises to overcome them, but this becomes unfeasible when they are heavily indebted or involved in corruption schemes with government actors, not to mention that many still do not recognize the importance of innovation in overcoming adverse economic conditions, especially in peripheral countries, for associating innovation with high risks. In this sense, the articulation among government, companies and universities aiming at regional development through innovation based on the model of a "triple helix" (Leydesdorff \& Etzkowitz, 1998) can be compromised.

The idea of "tolerance", on the other hand, by merely assuming coexistence, does not necessarily imply the recognition of differences in the dimension of wealth, nor does it bring substantive changes in relation to the views individuals have about others. The adoption of tolerance may even change the behaviour of creative professionals, making them less hostile to differences, but it does not necessarily incorporate profound changes in the identity of the involved actors, so that hierarchical and disparaging patterns of existing differences in societies would not be deconstructed by the formation of a "creative class". On the contrary, such standards could be incorporated or even accentuated in it. In line with Proctor-Thomson's (2009) argument, it is possible to affirm that the prominence of discourses on creativity, innovation or knowledge and the subordination of values associated with cultural activities - imbued with the concept of "creative class" - are parts of a process of commercialization of cultural activity, which does not strengthen the prospects for claims related to gender, sexual orientation, race, origin and social class at work in the creative sectors. The virtues of creative production are widely promoted and idealized, but women, LGBT and black people and low-income individuals are not necessarily allowed to free themselves from oppressive relationships through their participation in the "creative class", since professionals from sectors that make up this class reproduce hierarchical regimes that segregate, exclude and marginalize differences, particularly in developing countries, in which these regimes are more rooted in the light of historical gaps in terms of guaranteeing rights to such differences (Jesus, 2019).

In addition, the North Atlantic literature on "creative class" typically states that creative occupations tend to pay better wages and relate to levels of satisfaction above the more traditional sectors of the economy due to the producer's cultural and creative involvement with his/her product (Howkins, 2001). However, the reduction of staff, the outsourcing of production and the retrenchment of hierarchical levels have become even more intense in the face of the worsening political and economic crises in peripheral states. In such a context, as Bendassolli \& Wood (2010) and Tams (2003) already indicated, most professionals work in autonomous regimes and short-term work relationships, under non-favourable and precarious contractual conditions. Casual and contingent jobs predominate, 
characterized by instability and discontinuity in the light of variations in the demand conditions, the form of production per project, the pressures for innovation and differentiation and the very uncertain nature of the creative process. It is not uncommon that the work in a creative sector becomes a part-time occupation, for which formal education has little value and in which financial returns are uncertain.

More recently, Florida (2017) recognized that more qualified creative workers have been earning disproportionately more than the less qualified, which contributes to accelerating income inequality and accentuating socio-political polarization. However, the author does not examine the particularity and magnitude of these differences in the developing world, in which creative professionals continue to be the target of the same instabilities and forms of socioeconomic exclusion that prevailed in traditional sectors of the economy, such as unemployment and underemployment.

\section{Final Considerations}

It is possible to identify the existence of inadequacies and inconsistencies when applying the concepts of "creative economy", "creative city" and "creative class" to the reality of the Global South. Future studies can reveal more precisely that, in addition to reinforcing the gap between the wealth of innovators, investors and shareholders who control capital and those on whose work they depend, the notion of "creative economy" seemed to conceive, in several situations, that societies on the periphery of the capitalist system would be flat tables in which predefined formulas of socioeconomic governance applied to North Atlantic societies for the development of creative sectors could be replicated, with no sufficient consideration of the local particularities. Thus, there is an opportunity for these particularities to be further explored both by academia and decision makers in the treatment of such a concept. For example, while cultural and creative industries have been evaluated as new sources of employment and welfare for countries, Kaymas (2020) argues that these industries need a well-tailored cultural policy and the inclusion of culture into the sustainable development paradigm in Turkey.

The disregard or under-consideration of the specificities of the political and socioeconomic obstacles of the Global South have also become evident in the concept of "creative city", as developed by the main authors who have investigated the concept. For a more adequate mobilization of the concept to deal with realities from the periphery of the capitalist system, it would be important to adopt a culturally specific understanding of what creativity is, as well as the perception that the motivations for generating a creative city can come from different actors, according to the local political and socioeconomic circumstances. Furthermore, given the fragility of the criteria for defining the "creative class" in the light of the diversity of sectors that have their own needs and demands, it is essential to analyse the discrepancies in terms of wages, working conditions and the exercise of creativity among the professionals that operate within the same creative sector or among different industries to obtain a more specific mapping of the reality of the Global South. This analysis would make it possible to diagnose the difficulties related to the self-identification of individuals as members of this class and propose solutions for the elimination of hierarchical regimes that still segregate, exclude and marginalize differences not only in the creative sectors, but in the peripheral societies in which they are immersed.

\section{References}

Alexandri, M. B., \& Raharja, S. J. (2020). Development strategy of Bandung creative city through the performance improvement of creative industries. International Journal of Business and Globalization, 24(4), 560-568. https://doi.org/10.1504/IJBG.2020.106962

Araya, D. (2010). Educational policy in the creative economy. In D. Araya, \& M. A. Peters (Eds.), Education in the Creative Economy: Knowledge and Learning in the Age of Innovation (pp. 3-28). New York: Peter Lang Publishing Inc.

Bendassolli, P. F., \& Wood Jr, T. (2010). O paradoxo de Mozart: carreiras nas indústrias criativas. Organizações \& Sociedade, 17(53), 259-277. https://doi.org/10.1590/S1984-92302010000200002

Bendassolli, P. F., Wood Jr, T., Kirschbaum, C., \& Cunha, M. P. (2009). Indústrias criativas: definição, limitese possibilidades. RAE, 49(1), 10-18. https://doi.org/10.1590/S0034-75902009000100003

Bezerra, M. O. (2012). Estado, representação política e corrupção: Um olhar antropológico sobre a formação de fronteiras sociais. Crítica e Sociedade: Revista de Cultura Política, 2(2), 64-80.

Chantelot, S., Pérès, S., \& Virol, S. (2011). From Talent to Creative Cities: Toward a Conceptual Framework. 51st European Congress of the Regional Science Association International, New Challenges for European Regions and Urban Areas in a Globalised World. 
Closs, L. Q., Oliveira, S. R., Azevedo, P. R., \& Tirelli, C. (2014). Das Cidades aos Territórios Criativos: um Debate a Partir das Contribuições de Milton Santos. In Anais do XXXVIII Encontro da ANPAD (pp. 1-15). Rio de Janeiro.

Figueiredo, J. L. (2015). Economia criativa, cidade criativa e desenvolvimento. In E. A. S. Teixeira, \& S. B. Corrêa (Eds.), Economia criativa (pp. 27-47). Rio de Janeiro: E-papers.

Figueiredo, J. L., Grand Junior, J., \& Corrêa, S. B. (2019a). Urban restructuring in Rio de Janeiro: creative economy and new perspectives of development. Urbanities, 9, 91-107.

Figueiredo, J. L., Jesus, D. S. V., Robaina, D. T., \& Couri, C. L. (2019b). The development potential index of creative economy for Brazilian federal state capitals. Creative Industries Journal, 12(2), 185-203. https://doi.org/10.1080/17510694.2019.1610344

Florida, R. (2002). The rise of the creative class - and how it's transforming work, leisure, community and everyday life. New York: Basic Books. https://doi.org/10.4324/9780203997673

Florida, R. (2005). The flight of the creative class: the new global competition for talent. New York: Harper Collins.

Florida, R. (2017). The New Urban Crisis: How our cities are increasing inequality, deepening segregation, and failing the middle class-and what we can do about it. New York: Basic Books.

Florida, R., \& Mellander, C. (2020). The creative class and national economic performance. In Z. Chen, W. M. Bowen, \& D. Whittington (Eds.), Development Studies in Regional Science. Essays in Honor of Kingsley E. Haynes (pp. 553-575). Singapure: Springer. https://doi.org/10.1007/978-981-15-1435-7_26

Hartley, J. (2005). Creative Industries. London: Blackwell.

Howkins, J. (2001). The Creative Economy: How People Make Money From Ideas. London: Allen Lane.

Jesus, D. S. V. (2017). Saudade de mim: patrimônio cultural e economia criativa no Rio de Janeiro. In J. L. Figueiredo, \& D. S. V. Jesus (Eds.), Cidades Criativas: aspectos setoriais e territoriais (pp. 157-178). Rio de Janeiro: E-papers.

Jesus, D. S. V. (2019). Cidade próxima, região distante: os obstáculos a uma cidade-região no Estado do Rio de Janeiro. Grifos, 28(46), 115-135. https://doi.org/10.22295/grifos.v28i46.4822

Jesus, D. S. V., \& Dubeux, V. (2018). The crisis in private higher education in Brazil: main causes and possible solutions. International Journal for Innovation Education and Research, 6(1), 35-46.

Jesus, D. S. V., \& Kamlot, D. (2017). Stuck in the middle of nowhere: cultural policy, development and creative industries in Brazil. Creative Industries Journal, 10(2), https://doi.org/10.1080/17510694.2017.1318255

Jesus, D. S. V., \& Kamlot, D. (2018). Planos para uma cidade criativa: propostas para a economia criativa nas eleições para a Prefeitura do Rio de Janeiro de 2012 e 2016. Latin American Journal of Business Management, $9(2), 37-50$.

Karvelyte, K. (2020). Shifting meanings in changing contexts: the role of the creative city in Shanghai, Hong Kong and Taipei. International Journal of Cultural Policy, 26(2), 166-183. https://doi.org/10.1080/10286632.2018.1479748

Kaymas, S. (2020). Is development possible without cultural policies? Rethinking creative industries and sustainable development in the case of Turkey. Creative Industries Journal, 13(1), 72-92. https://doi.org/10.1080/17510694.2019.1652026

Kerrigan, S., McIntyre, P., Fulton, J., \& Meany, M. (2020). The systemic relationship between creative failure and creative success in the creative industries. Creative Industries Journal, 13(1), 2-16. https://doi.org/10.1080/17510694.2019.1624134

Kolobova, S. (2020). Renovation of Moscow as a Subprogram of Creation of a Creative City. IOP Conf. Series: Materials Science and Engineering, 753(5), e062003. https://doi.org/10.1088/1757-899X/753/6/062003

Landry, C. (2011). Prefácio. In A. C. F. Reis, \& P. Kageyama (Eds.), Cidades criativas: perspectivas (pp. 7-15). São Paulo: Garimpo de Soluções.

Landry, C., \& Bianchini, F. (1998). The creative city. London: Demos. 
Leydesdorff, L., \& Etzkowitz, H. (1998). The Triple Helix as a Model for Innovation Studies. Science \& Public Policy, 25(3), 195-203.

Lopes, B., \& Amaral, J. N. (2008). Políticas Públicas: conceitos e práticas. Belo Horizonte: Sebrae MG.

Mainwaring, S. (2003). Introduction: democratic accountability in Latin America. In S. Mainwaring, \& C. Welna (Eds.), Democratic accountability in Latin America (pp. 3-33). New York: Oxford Press. https://doi.org/10.1093/0199256373.003.0001

Mann, M. (2012). The Sources of Social Power: Volume 4, Globalizations, 1945-2011. Cambridge: Cambridge University Press.

Messias, F., Nascimento, E., \& Silva, C. (2020). A economia criativa na arena da sustentabilidade. Pós. Revista Do Programa De Pós-Graduação Em Arquitetura E Urbanismo Da Fauusp, 27(50), e161954. https://doi.org/10.11606/issn.2317-2762.posfau.2020.161954

Miguez, P. (2007). Economia criativa: uma discussão preliminar. In G. M. Nussbaumer (Ed.), Teorias e políticas da cultura: visões multidisciplinares (pp. 95-113). Salvador: Edufba.

Miles, S. (2014). A revitalização movida pela cultura funciona?. In L. Goldenstein, P. Rosselló, \& F. Arruda (Eds.), Regeneração urbana através da cultura funciona (pp. 124-132). London, São Paulo: The British Council.

Proctor-Thomson, S. B. (2009). Creative differences: the performativity of gender in the digital media sector. $P h D$ Thesis, Lancaster University, Lancaster.

Reis, A. C. F. (2006). Economia da cultura e desenvolvimento sustentável: O caleidoscópio da cultura. Barueri: Manole.

Reis, A. C. F. (2008). Introdução. In A. C. F. Reis (Ed.), Economia criativa como estratégia de desenvolvimento: uma visão dos países em desenvolvimento (pp. 14-49). São Paulo: Itaú Cultural.

Reis, A. C. F. (2011). Revelando o invisível: os enredados fios de ligação entre ícones culturais e os processos de transformação urbana. In A. C. F. Reis (Ed.), Anais do Seminário Internacional Cultura e Transformação Urbana (pp. 10-14). São Paulo: SESC Belenzinho.

Rendra, A., \& Rahmat, R. (2020). Bandung Creative Class: Fostering Creative Characters of Citizens in Bandung City as a Strengthening of 21 st Century Competency. Proceedings of the 6th International Conference of Project Management (ICPM) Malang 2020. https://doi.org/10.32535/jicp.v2i4.776

Santos, M. (1996). Por uma geografia nova. São Paulo: Hucitec.

Schwab, K. (2016). The fourth industrial revolution. Geneva: World Economic Forum.

Scott, A. J. (2019). City-regions reconsidered. EPA: Economy and Space, 51(3), 1-27. https://doi.org/10.1177/0308518X19831591

Tams, E. (2003). The gendering of work in Sheffield's Cultural Industries Quarter (CIQ). PhD Thesis, Sheffield Hallam University, South Yorkshire.

Towse, R., \& Hernández, T. N. (2020). Introduction. In R. Towse, \& T. N. Hernández (Eds.), Handbook of Cultural Economics (pp. 1-8). Cheltenham: Edward Elgar Publishing. https://doi.org/10.4337/9781788975803.00006

Trip, J. J. (2009). Creative city development in the Lisbon Strategy: evidence from Dutch ERDF allocation. In City Futures '09: An International Conference Globalism and Urban Change. Madrid.

Venturelli, S. (2000). From the Information Economy to the Creative Economy: Moving Culture to the Center of International Public Policy. Washington, D.C.: Center for Arts and Culture.

Vivant, E. (2012). O que é uma cidade criativa?. São Paulo: Senac.

Vlassis, A., \& Beukelaer, C. (2019). The creative economy as a versatile policy script: exploring the role of competing intergovernmental organizations. Media, Culture \& Society, 41(4), 502-519. https://doi.org/10.1177/0163443718810913 